\title{
紙の少化試験のための加速少化処理条件について
}

三菱製紙秼 高 橋

\section{Some Surveys on Accelerated Ageing Conditions for Deterioration Test of Paper and Board}

\author{
Atsushi Takahashi \\ Mitsubishi Paper Mills, Ltd.
}

\begin{abstract}
As an interest in permanence of paper has been increasing, the Testing Standards Committee of J. TAPPI recently prepared J. TAPPI Testing Standard No. 50 「Accelerated Ageing Conditions for Paper and Board].

In preparing it, the committee carried out some surveys including the conditions which are taken actualy in this country, foreign standard methods, literatures concerning effects of moisture, and performance of temperature-humidity chambers. This is a report of the surveys.
\end{abstract}

\section{1. まえがき}

近年，図書館の蔵書がボロボロになりつつあるとい 万問題がクローズアップされて以来，紙の保存性に対 する関心が我が国に批いても急速に高まってきた。 それに従い，当然保存性の評価をいがして合理的 K，乙かる短時間飞行らかが問題となってきている。 勿論，数十年あるいはそれ以上の長時間にわたる紙 の劣化を実際に行らことは無理であり，その代替とし て普通加速劣化処理が行われる。その方法としては光 などによる処理もあるが，一般には加熱または加熱と 加湿によって劣化を促進させる方法が広く行われてい る。

しかし我が国には，電気絶縁紙等特殊な用途の紙を 対象とするものを除いては加速劣化の条件について公 的な規格は無く，製紙メ一カーはじめ各機関では海外 の規格や文献を参考に，処理設借の性能も考虑しなが らそれぞれ独自に設定しているのが実情である。

当試験規格委員会では，この処理条件の標準化を図 ることとし，この度 J. TAPPI 試験方法 No. 50-87 「紙及び板紙の加速劣化処理条件」を制定したが，そ の過程に括いて，当委員会ではアンケートや海外規格 の調査など一連の調查活動を行ったので，その内容を 中心にここに取りまとめた。

\section{2. 国内の現状一ーアンケート調查の結果}

当委員会では内容の検討に先立って国内での実情を 把握するため, 61 年 4 月に主な製紙メーカー, 試験研 究機関及び大学の協力を得てアンケート調查を実施し た。 32 機関に依頼し， 28 機関（らち 2 機関は各 2 事 業所）加 30 件の回答を得た（表 1 )。

表 1 フンケート依頼先の数及び回答状況

\begin{tabular}{|c|c|c|c|c|}
\hline & \multirow{2}{*}{ 依頼 } & \multicolumn{2}{|c|}{ 回答 } & \multirow{2}{*}{ 回答率 } \\
\hline & & 有 & 無 & \\
\hline 製紙メーカー & 22 & $18(20)$ & 4 & $82 \%$ \\
\hline 試験研究機関 - 大学 & 10 & 10 & 0 & $100 \%$ \\
\hline 計 & 32 & $28(30)$ & 4 & $88 \%$ \\
\hline
\end{tabular}

設問に当っては，長期の経時に伴らいわゆる“書籍 の崩壊”をひきおこすよらな紙の劣化を対象とするこ ととし，書籍を店頭に並べた場合の退色中電気絶縁紙 の耐久性などは対象外とすることを注記した。

\section{1 劣化試驗実施状況}

先ず少化試験を行ったことがあるかどらか，行った

* 現 紙パルフ技術協会

前 紙パルプ試験規格委員会副委員長 
表 2 少化試験実施状況

\begin{tabular}{|c|c|c|c|}
\hline & & 回答数 & $\%$ \\
\hline 1. & $\begin{array}{l}\text { 日常絶えず又はしばしば行っ } \\
\text { ている }\end{array}$ & 1 & 3 \\
\hline 2. & 必要に応じて時々行ら & 14 & 47 \\
\hline 3. & $\begin{array}{l}\text { めったにないが行らことがあ } \\
\text { る, 又は行ったことがある }\end{array}$ & 7 & 23 \\
\hline 4. & $\begin{array}{l}\text { 以前にかなり行ったことがあ } \\
\text { るが，現在は行っていない, } \\
\text { 又は時々しか行っていない }\end{array}$ & 2 & 7 \\
\hline 5. & 行ったことなし & 6 & 20 \\
\hline
\end{tabular}

ことがあるとすればその程度について質問したところ 表 2 の通りであった。行ったことがないのは $20 \%$ の みで，大体行った経験があり，その中では“必要に 応じて時々行ら”が過半数を占めた。

\section{2 処理条件}

1) 乾式・湿式の別

加熱のみ行い，湿度については特に調節せずに乾 蜗状態とする方法（以下乾式という）と，温度，湿 度とも所定の值に調節する方法（以下乾式という） のどららを採用しているか回答を分類した（表 3 )。

\section{表 3}

\begin{tabular}{|c|c|c|c|}
\hline & & 件数 & $\%$ \\
\hline 乾 & 式 & 19 & 70 \\
\hline 湿 & 式 & 8 & 30 \\
\hline
\end{tabular}

乾式，湿式を併用している事業所が 3 個所あり， これらを含め延 27 件中 $70 \%$ が乾式であり，湿式で 行っているところは $30 \%$ にとどまった。

乾式法が多く行われているのは装置が湿式法より 簡易であることに加之. TAPPI Standard にもそ の規格が定めら：さおり，また湿度の影䇾が大きい ことが広く知られるようになったのが比較的新しい ためと考えられる。

2) 温湿度条件

\section{表 4 乾式の条件}

\begin{tabular}{ccc} 
& 件数 & $\%$ \\
\hline $105^{\circ} \mathrm{C}$ & 15 & 79 \\
$100^{\circ} \mathrm{C}$ & 2 & 11 \\
$150^{\circ} \mathrm{C}, 200^{\circ} \mathrm{C}$ & 1 & 5 \\
不 明 & 1 & 5 \\
\hline 計 & 19 件
\end{tabular}

湿式の条件

\begin{tabular}{ccc} 
& 件数 & $\%$ \\
\hline $80^{\circ} \mathrm{C}, 80 \% \mathrm{R} \mathrm{H}$ & 4 & 50 \\
$80^{\circ} \mathrm{C}, 90 \% \mathrm{R} \mathrm{H}$ & 1 & 13 \\
$85^{\circ} \mathrm{C}, 95 \% \mathrm{R} \mathrm{H}$ & 1 & 13 \\
$80^{\circ} \mathrm{C}, 65 \% \mathrm{R} \mathrm{H}$ & 1 & 13 \\
$80 \sim 90^{\circ} \mathrm{C}, 60 \sim 65 \% \mathrm{R} \mathrm{H}$ & 1 & 13 \\
\hline 計 & 8 件
\end{tabular}

表 4 に示すように乾式では $105^{\circ} \mathrm{C}$ が大勢であるが， 湿式では $80^{\circ} \mathrm{C} 、 80 \% \mathrm{RH}$ を中心に，80 $90^{\circ} \mathrm{C}, 60$ 〜95\% RH の範囲でハラッキが出た。湿式の場合. 今まで特に準拠できるような規格がなかったので， その温湿度条件の設定は文献を参照することになる わけであるが，実際問題として数日から数週間もか かるかなり長いエージング時間を少しでも短くした いといら願望から, 恒温恒湿器の性能が正しく維持 できる範用内で，なるへく䈣しい条件になるように 決められることが多かったと思われる。

3）エージング時間

乾式で 15 分〜30日（720 時間)，湿式で 1 日〜56

日（1,344 時間）の範囲の回答が得られた。

4）空気の流動

表 5

\begin{tabular}{cccc:c} 
& & & \multicolumn{2}{c}{ 件数内訳 } \\
& 件数 & $\%$ & 乾式 & 湿式 \\
\hline 強 制 循 環 & 20 & 77 & 13 & 7 \\
自然 循 環 & 6 & 23 & 5 & 1 \\
\hline 計 & 26 件 & & 18 件 & 8 件
\end{tabular}

おおむね強制循環方式が使われているが，乾式で は自然循環方式が 5 件みられた（表 5 )。なお，湿 式の自然循環方式 1 件の回答には, 空気の流動をさ せないと值のバラッキが大きいように感じるとのコ メントが付いていた。

強制循環の場合，その風速あるいは風量について も質問したが，回答は 2 件（1.5〜2 m/sec 及び 50 $l / \mathrm{min})$ のみであった。

表 6 準拠した試験法

\begin{tabular}{|c|c|c|c|c|}
\hline & \multirow[b]{2}{*}{ 件数 } & \multicolumn{3}{|c|}{ 件数内訳 } \\
\hline & & $\%$ & 乾式 & 湿式 \\
\hline TAPPI & 14 & 52 & 14 & - \\
\hline 文 献 & 6 & 22 & 3 & 3 \\
\hline “特になし”又は記截なし & 7 & 26 & 2 & 5 \\
\hline 計 & 27 件 & & 19 件 & 8 件 \\
\hline
\end{tabular}




高橋 愿

\section{3 準拁した試験法}

条件を設定するに当って，準拠した試験法（規格） について答えてもらった（表 6 )。

乾式の場合はやはり TAPPI Standard T 453 (105 $\left.{ }^{\circ} \mathrm{C}\right)$ が多かったが，湿式では文献 3 件にとどまった。

TAPPI と ISO の湿式法が使われていないのは, これらの温湿度の発生設備が容易に得にくいこと， 湿度が低いことのほか，これら規格の制定が極く最近 （1985 年）であるなどによるものと思われる。

\section{4 装}

恒温器, 恒温恒湿器のメーカーは多数あると言われ， そのことを反映して使われている装置名は多種多様で あった。手作りも 1 件あった。

\section{5 評価方法}

参考にエージング処理後の試料の評価方法について

も質問した（表 7,8$)$ 。

表 7 項 目 件数 (延)

. 強 度 38 内訳耐折 22

引張 8

引裂 4

その他 4（破裂，仕事量，破 断伸び，濡れ強度）

2. 色関係 11 色 - 白色度, 色度, 着色, 裉色性

3. その他 3 ヤング率, 表面反射スペクトル, $\mathrm{pH}$ 計 52 件

\section{表 8 表示方 法}

件数(延)

1. エージング前後の比較, 変化率, 残存率など 8

2. 加熱時間との対比（グラフ）など 6

3. 耐折強さ半隇までの加熱時間 2

4. 標準中性紙之比較

5. 記載なし

計

表 9 海外・国内規格一覧

\begin{tabular}{|c|c|c|c|c|}
\hline 規 格 & 号 & 題 & 処理条件 & 備 \\
\hline TAPPI & $\mathrm{T} 453 \mathrm{su}-70$ & $\begin{array}{l}\text { Effect of heating on folding endurance } \\
\text { (Relative stability of paper) }\end{array}$ & 乾式 $105 \pm 2^{\circ} \mathrm{C}$ & T $453 \mathrm{pm}-85$ 一移行 \\
\hline TAPPI & $\mathrm{T} 453 \mathrm{pm}-85$ & $\begin{array}{l}\text { Effect of dry heat on properties of } \\
\text { paper }\end{array}$ & 乾式 $105 \pm 2^{\circ} \mathrm{C}$ & $\begin{array}{l}\text { ISO } 5630 / 1 \text { 之実質 } \\
\text { 的に同一 }\end{array}$ \\
\hline TAPPI & T $544 \mathrm{pm}-85$ & $\begin{array}{l}\text { Effect of moist heat on properties of } \\
\text { paper and board }\end{array}$ & $\begin{array}{l}\text { 湿式 } 90 \pm 0.5^{\circ} \mathrm{C}, \\
25 \pm 1 \% \mathrm{RH}\end{array}$ & $\begin{array}{l}\text { ISO } 5630 / 2 \text { と実質 } \\
\text { 的级一 }\end{array}$ \\
\hline ISO & $5630 / 1$ & $\begin{array}{l}\text { Paper and board-Accelerated ageing- } \\
\text { Part } 1: \text { Dry heat treatment }\end{array}$ & 乾式 $105 \pm 2^{\circ} \mathrm{C}$ & 1982 年 12 月制定 \\
\hline ISO & $5630 / 2$ & $\begin{array}{l}\text { Paper and board-Accelerated ageing- } \\
\text { Part } 2: \text { Moist heat treatment at } 90^{\circ} \mathrm{C} \\
\text { and } 25 \% \text { relative humidity }\end{array}$ & $\begin{array}{l}\text { 湿式 } 90 \pm 0.2^{\circ} \mathrm{C}, \\
25 \pm 0.5 \% \mathrm{RH}\end{array}$ & 1985 年 11 月制定 \\
\hline ISO & $5630 / 3$ & 未 詳 & $\begin{array}{l}\text { 湿式 } 80^{\circ} \mathrm{C}, \\
65 \% \mathrm{RH}\end{array}$ & 制定準備中 \\
\hline ISO & $\begin{array}{l}5630 / 4 \\
(\text { DRAFT) }\end{array}$ & $\begin{array}{l}\text { Paper and board-Accelerated ageing- } \\
\text { Part } 4: \text { Dry heat treatment at } 120 \text { or } \\
150^{\circ} \mathrm{C}\end{array}$ & $\begin{array}{c}\text { 晖式 } 120 \pm 2^{\circ} \mathrm{C} \text { or } \\
150 \pm 2^{\circ} \mathrm{C}\end{array}$ & $\begin{array}{l}\text { 1985年ドラフト作成 } \\
\text { 電気維縁紙のような } \\
\text { 高純度の紙に適用 }\end{array}$ \\
\hline ASTM & D 776-65 & $\begin{array}{l}\text { Relative stability of paper (Effect of } \\
\text { heat on folding endurance) }\end{array}$ & 乾式 $105 \pm 2^{\circ} \mathrm{C}$ & \\
\hline JIS & C $2111-84$ & 䉓気絶縁紙試験方法 & 乾式 $140 \pm 3^{\circ} \mathrm{C}$ & \\
\hline J. TAPPI & No. 50-87 & 紙及び板紙の加速劣化処理条件 & $\begin{array}{r}\text { 乾式 } 105 \pm 2^{\circ} \mathrm{C} \\
\text { 湿式 (1)法 } 80 \pm 2^{\circ} \mathrm{C}, \\
65 \pm 3 \% \mathrm{RH} \\
\text { (2)法 } 90 \pm 2^{\circ} \mathrm{C}, \\
25 \pm 2 \% \mathrm{RH}\end{array}$ & \\
\hline
\end{tabular}


やはり強度関係が圧倒的に多く，その中でも予想通 り耐折が特に多い。これらを強度残存率，加熱時間に 対してプロットしたグラフなどでみる方法が最も一般 的に行われている。

\section{3. 海外規格}

加速劣化のための条件を規定した海外の規格を国内 のものも含め表 9 に示した。大きく分けて乾式法と湿 式法があるが，このうち湿式法については，ようやく 最近になって制定され始めたといらのが実情である。

Luner ${ }^{1)}$ る次のようにのぺている。“われわれの研 究や他の研究者らの結果は, 劣化速度に大きく影響す るのは湿度であることを示しており, 従って一定の湿 度で加速劣化を行らことが, 乾燥器による劣化よりも もっと自然少化に近い状態をシミュレートしていると 結論している。紙の耐候性について ASTM, TAPPI 試験法のどちらる加熱乾燥だけしか指示していないこ とは驚きである”と。

\section{1 乾 式 法}

このうち乾式法は TAPPI, ASTM にみられるよう にかなり以前から制定されており，その条件も電気絶 縁紙のような特殊な紙を目的とした ISO 5630/4 を除 いて，いずれも $105 \pm 22^{\circ} \mathrm{C}$ に統一されているので特に 問題のないところである。またその温度も紙の水分測 定の祭の乾燥温度と同一で対処し易い。

\section{2 湿 式 法}

一方, 湿式法については, 最近 TAPPI と ISO で 相次いで $90^{\circ} \mathrm{C}, 25 \% \mathrm{RH}$ の比較的低湿度の条件の規格 が制定された。この 2 つの規格 TAPPI T 544 pm-85 と ISO $5630 / 2$ は実質的に同じものである。

これらの規格では $90^{\circ} \mathrm{C}, 25 \%$ の条件を発生・維持 するための装㯰も示している。図 1 がそれで，右側の $57.3^{\circ} \mathrm{C}$ のオイルパスに入れられた 2 本のペッセルにお いて水蒸気で飽和した $57.3^{\circ} \mathrm{C}$ の空気を作り，それを左 側のオイルバスでュイルチューブを通して $90^{\circ} \mathrm{C}$ まで 昇温した後, 同オイルパス中の試料を入れたエージン グペッセルに送り込む仕組みになっている。

$57.3^{\circ} \mathrm{C}$ の飽和水蒸気压が $90^{\circ} \mathrm{C}$ におけるそれの $1 / 4$, 即ち $25 \%$ であることに基づく。

本装置は湿度発生の基礎的な原理を利用した，シン プルではあるが精密な温湿度発生装置で, 湿度センサ 一の検定用装置や必要な温湿度を得る実験装瓃として, 紙以外の分野で利用されている。

しかし, $90^{\circ} \mathrm{C}, 25 \% \mathrm{RH}$ という条件は商温低湿のゆ えに国内で玩在一般に市販され，広く使用されている 恒温恒湿器では括拈むね制御䈖囲外にある（図 10）。 このため現段階でこの条件で処理しょらとすれば, 装 圆について何らかの対応が必要となる。

なお，この ISO $5630 / 2$ では温湿度の許容差が士 $0.2^{\circ} \mathrm{C}$ ， $0.5 \% \mathrm{RH}$ とかなり小さい点が目につく。

ISO では $80^{\circ} \mathrm{C}, 65 \% \mathrm{RH}$ の条件を ISO $5630 / 3$ と して制定する旨表明している。このことが J. TAPPI 規格の内容に大きな影䇾を与えたが，まだドラフトも 発行されていない段階にあり，その詳細について情報 を入手するよう努力しているところである。

\section{4. 加速劣化における湿分の影響について}

紙の加速少化速度に影幚を及ぼすと考えられる因子 は幾つもあるが，近年その中でも湿度（水分）の影響 が大きいことが明かになってきた。

そして今回の J. TAPPI 試験方法の制定に当っても, 湿度の条件をどのレベルに設定すべきか，この点が装 直の性能との関連もあり，最も大きな焦点となった。 このことから, 特に湿度が加速少化速度に及ぼす影

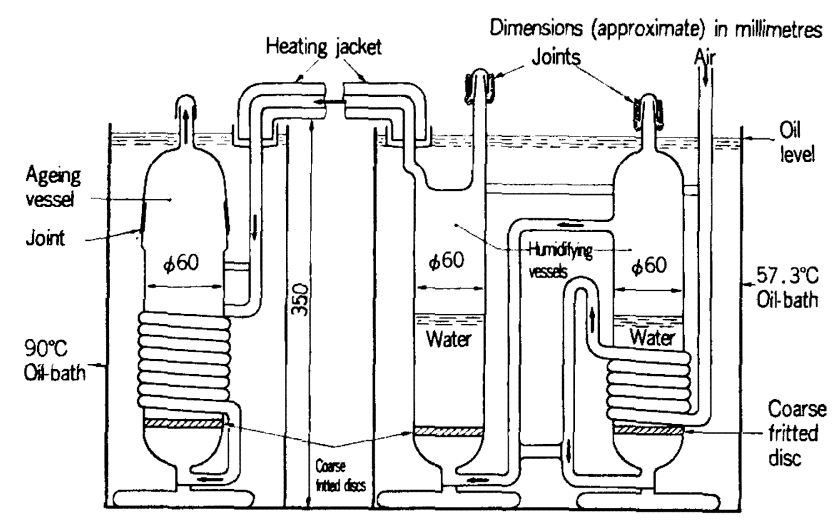

図 1 温湿度発生装置 (ISO $5630 / 2$ 記载) 
響を扱った幾つかの文献について要点を紹介したい。

\section{1 海外の文献}

当委員会ではその代表的文献であり TAPPI, ISO の規格を制定する上で学術的根拠を与えたアメリカ財 務省証券印刷局の技師である Graminski らの 2 編の 文献2) 3) を大藏省印刷局研究所の御努力で入手するこ とができ，今回の審議に役立てることができた。

2 編とも $0.1 \mathrm{~N}$ 塩酸で脱塩処理した NBKP によっ $て 70 \mathrm{~g} / \mathrm{m}^{2}$ に作られた手抄さシートを使用し，温度， 湿度, エージング時間を種々に変えて加速劣化处理を 行い, 耐折強さ, 引張り強さ, 白色度, アルカリ溶解 度，銅価， $\mathrm{pH}$ などを測定することによって，紙の加 速劣化に淤引る水分（湿度）と劣化速度の関係を解明 しょらと試みた論文である。

1978 年に発表された論文 ${ }^{2}$ は温度を 60 乃至 $90^{\circ} \mathrm{C}$, 湿度を 0 から $50 \%$ RH (一部 75\% RH) まで変えて試 験した結果として，エージングの空気が乾燥している 場合にはどの温度であっても, 例外として湿潤強度が 著しく増加したほかは，物理的性質はほとんと変化が なく，またいずれの場合も物理的性質の劣化，あるい。 は化学的性質の変化の速さは相対湿度が增えるととも に增加した，と述べている。

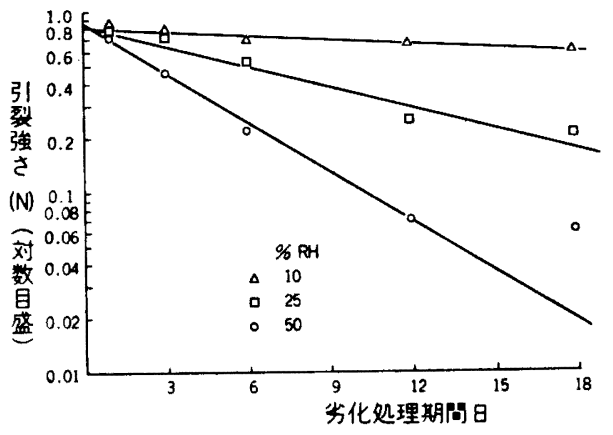

图 2 引裂強さの変化 $\left(90^{\circ} \mathrm{C}\right)$

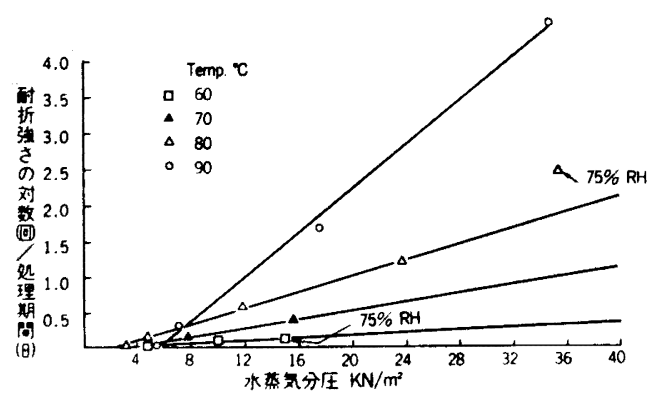

図 3 水蒸気分圧と耐折強さの 劣化速度の関係

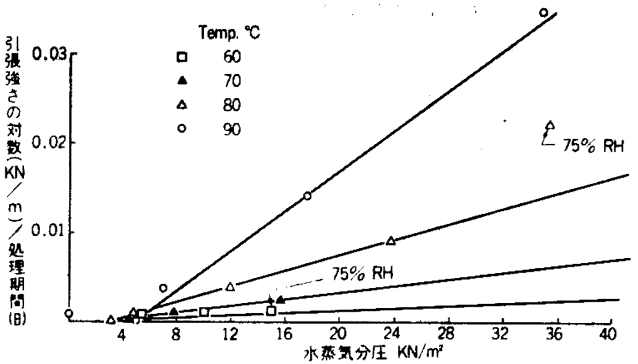

図 4 水蒸気分圧と引張強さの 劣化速度の関係

多数の図と表の中から 3 点を図 $2 \sim 4$ 亿例示した。 図 2 の引裂強さ，図 3 の耐折強さ，図 4 の引張強さの いずれも湿度の影響を強く受けていることが分る。

Graminski のも5一つの論文 ${ }^{3)}$ は湿度範囲を $90 \%$ RH まで拡げて同様の試験を行ったもので，その中で 以下のように述べている。

すべての物理的性質の変化率は，エージング環境中 の水蒸気量に比例して増加した。紙の劣化速度に与兄 る水分の影響は大きく，最も重要な環境因子であろう。

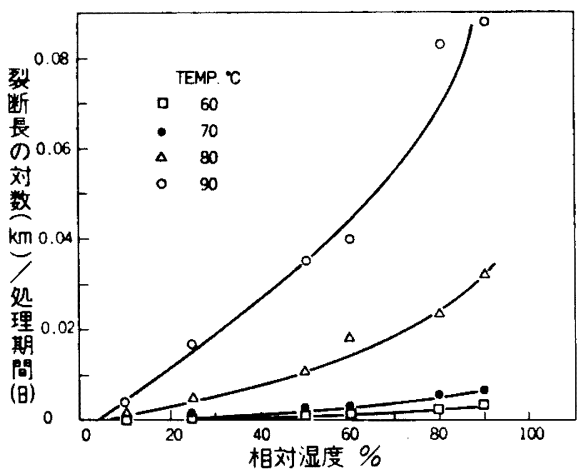

図 5 相対湿度とゼロスパン引張強さの 劣化速度の成係

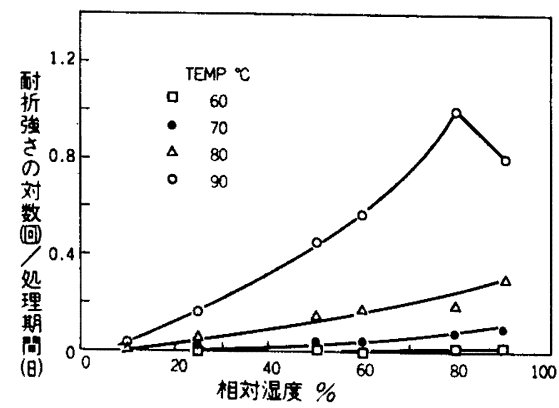

図 6 相対湿度と耐折強さの劣化速度の 関係 


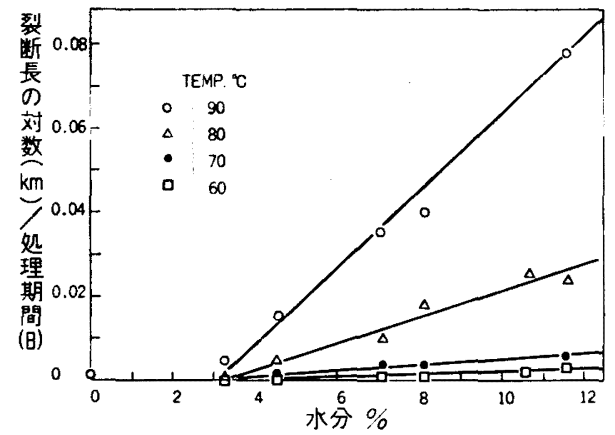

図 7 水分とゼロスパン引張強さの 贫化速度の関係

図7のよ5に紙の水分に対して劣化速度をプロット すると直線関俰が得られる。それらの直線が原点より かなり大きな点で $\mathrm{x}$ 軸を切っていることは，結合水の 一部が不活性であることを示しており興味深い。

その直線の㑯きが大きいことから，信頼度の高い結 果を得るためには，環境条件のコントロールが非常に 重要であることが分かる。

この結果はまた， $100 \sim 105^{\circ} \mathrm{C}$ の単純な熱乾ェ一シ ングではセルロースの結合水量は非常に少く，極めて 不活性であり，幻の結果に終ることを示している。

処理条件として $90^{\circ} \mathrm{C}$ 以上の温度が高過ぎるという 結果は得られなかったが，信頼度の高いデータを得る ためには, $80^{\circ} \mathrm{C}$ 以上の温度に拁いては温度, 湿度の 両方を極めて正確にコントロールしなければならない。 以上の通り述へ，秖の加速少化処理における湿分の 重要性を強調している。

\section{2 国内の文献}

国内には湿度が加速少化に及ぼす影響について述へ た文献はあまり見当らないが，以下に東京農工大学大 江はかの 2 編の論文を紹介する。

「紙の劣化速度に関寸る検討」いにおいて大江汪か は酸性上質紙，中性上質紙，和紙の劣化速度を測定， 対比し，また少化速度に影響する諸因子について検討 を行っているが，その中で少化処理に拈ける湿度の影 響に関して，劣化速度定数を使って图 8 及び表 10 の ようなデータを示している。

そして，㕍皮紙は楮紙よりも，中性紙は酸性紙より も，湿度による影響を受け難かった，と述へててる。 なお，ここで少化速度定数とは，ある特性值（特性 值によってはその対数）と処理時間の関係が一般に図 9に示すよ5に直線関係になることから，その直線の 傾さを劣化し易さの指数として表わしたものである。

「紙の劣化速度に関する試験」5) は古綎のパルブ緎

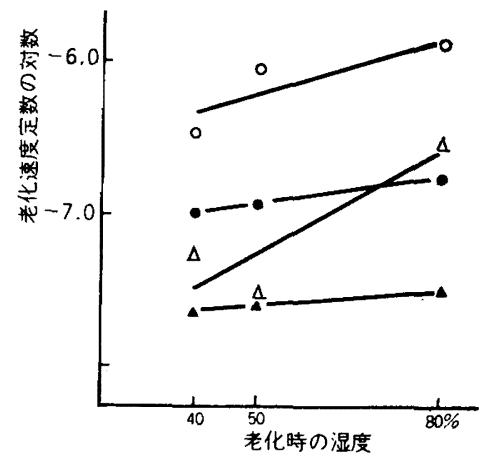

図 8 老化速度定数と老化湿度の関係 $\left(80^{\circ} \mathrm{C}\right)$

○酸性紙○中性 紙 $\triangle$ 楮和紙

$\Delta$ 㕍皮和紙

表 $1080^{\circ} \mathrm{C}$ 老化における湿度と老化速度 および相対寿命

\begin{tabular}{|c|c|c|c|c|}
\hline 試 & 料 & $\underset{\%}{\text { 相対湿度 }}$ & 老华速度 & 相対寿命* \\
\hline \multirow{3}{*}{\multicolumn{2}{|c|}{ 酸 性 紙 }} & 80 & $1.1 \times 10^{-6}$ & 1.0 \\
\hline & & 50 & $9.4 \times 10^{-7}$ & 1.2 \\
\hline & & 40 & $5.8 \times 10^{-7}$ & 1.9 \\
\hline \multirow{3}{*}{\multicolumn{2}{|c|}{ 中 性 紙 }} & 80 & $4.2 \times 10^{-7}$ & 2.6 \\
\hline & & 50 & $3.3 \times 10^{-7}$ & 3.3 \\
\hline & & 40 & $3.1 \times 10^{-7}$ & 3.6 \\
\hline \multirow{3}{*}{\multicolumn{2}{|c|}{ 雁皮和紙 }} & 80 & $1.7 \times 10^{-7}$ & 6.7 \\
\hline & & 50 & $1.6 \times 10^{-7}$ & 6.7 \\
\hline & & 40 & $1.5 \times 10^{-7}$ & 7.1 \\
\hline \multirow{3}{*}{\multicolumn{2}{|c|}{ 楮 和 紙 }} & 80 & $4.7 \times 10^{-7}$ & 2.3 \\
\hline & & 50 & $1.7 \times 10^{-7}$ & 6.7 \\
\hline & & 40 & $2.3 \times 10^{-7}$ & 4.8 \\
\hline \multirow{2}{*}{\multicolumn{2}{|c|}{$\begin{array}{l}\text { マ = } \\
\text { 手すきシー紙 } \\
\text { 严抄きシート } \\
\text { 榤 }\end{array}$}} & 80 & $1.5 \times 10^{-7}$ & 7.1 \\
\hline & & 80 & $1.3 \times 10^{-7}$ & 8.3 \\
\hline
\end{tabular}

*老化速度の逆数で, 酸性紙 $80^{\circ} \mathrm{C}, 80 \%$ R.H. の值 を 1 とする。

稚の劣化を検討する目的で行った試験のまとめである。 市販上質紙（中性紙及び酸性紙），クラフトライナ, TMP の手抄きシートを用いて加熱，加湿による耐折 強さ, 白色度, $\mathrm{pH}$ など紙の諸特性の变化を少化速度 定数としてとらえ，論じている。

この中で，湿度の影響に関するものとして, 温度 80 ${ }^{\circ} \mathrm{C}$ ， 相対湿度 50，65，80\% RH の条件で処理した上 質紙 5 種類について，劣化処理時間之白色度の相威係 数及び少化速度定数が示され，相対湿度が高いほど劣 化速度定数は大きくなることが涩められた（表 11）。 


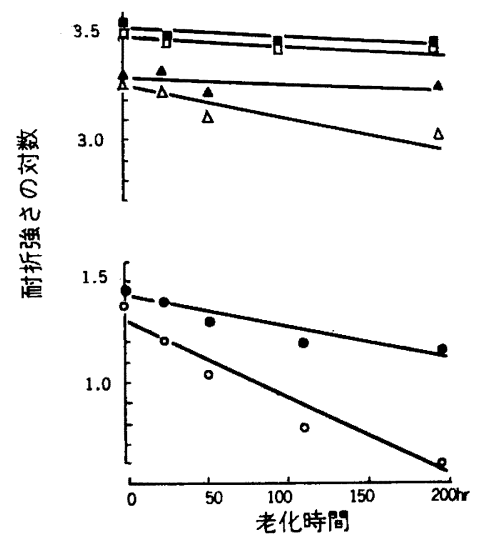

図 $980^{\circ} \mathrm{C}, 80 \% \mathrm{RH}$ で老化する時の耐折強さ (対数) の低下

○酸 性 紙

$\triangle$ 楮和紙

中性 紙

$\square マ ニ ラ$ 麻パルプ紙

A 確皮和紙

D梅パルプ紙

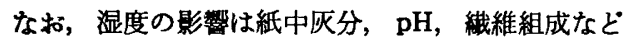
によっても影響されるようで，特性值によっては必ず しもはっきりした相関を示さない場合も見られる。

\section{5. 恒温恒湿器の性能について}

適正な加速劣化処理を行うためには，当然のことな がらその条件を十分満たす性能を持った装固が入手で きなけれぱならない。ここでは一般市肘の恒温恒湿器 の性能について簡単に触れてみたい。

\section{1 温湿度制御筑囲}

恒温恒湿器のメーカーは国内に相当数ある模様であ るが，らち数社の標準的な恒温恒湿器について温湿度 制御範囲を図 10 によとた。メーカーによって制御 範囲に若干の差はあるが，パターンにそれ程大きな違 いは見られない。メーカーの話では，その機構上，高 温低湿の条件を出しにくいことと，ユーザーからその

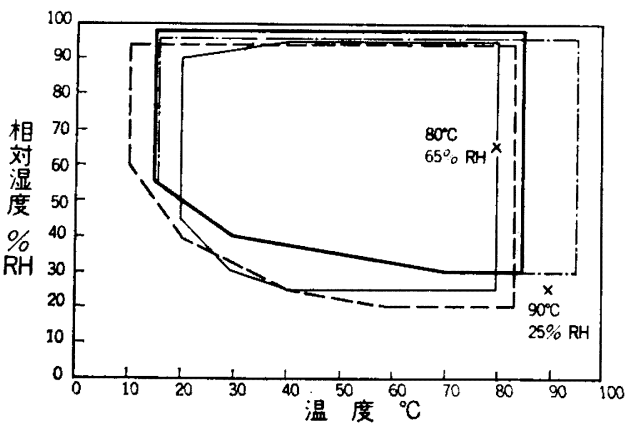

図 10 恒温恒湿器の温湿度制御篹囲
表 11 上質紙試料の白色度の劣化速度定数

\begin{tabular}{|c|c|c|c|c|}
\hline \multirow[b]{2}{*}{ 試 料 } & \multicolumn{2}{|c|}{ 老化条件 } & \multirow[b]{2}{*}{ 相関係数 } & \multirow{2}{*}{$\begin{array}{c}\text { 少化速度定数 } \\
\left(\mathrm{sec}^{-1}\right)\end{array}$} \\
\hline & $\stackrel{\left.{ }^{\circ} \mathrm{C}\right)^{\circ}}{\text { 度 }}$ & $\mid \begin{array}{c}\text { 湿 } \\
\text { \% } \mathrm{RH}\end{array}$ & & \\
\hline \multirow[t]{5}{*}{ A } & 65 & 65 & 0.949 & $5.59 \times 10^{-6}$ \\
\hline & 70 & 65 & 0.912 & $8.26 \times 10^{-6}$ \\
\hline & 75 & 65 & 0.959 & $1.32 \times 10^{-5}$ \\
\hline & 80 & 65 & 0.881 & $1.79 \times 10^{-5}$ \\
\hline & 85 & 65 & 0.941 & $2.24 \times 10^{-5}$ \\
\hline \multirow[t]{5}{*}{ B } & 65 & 65 & 0.992 & $2.22 \times 10^{-6}$ \\
\hline & 70 & 65 & 0.994 & $4.17 \times 10^{-6}$ \\
\hline & 75 & 65 & 0.980 & $8.45 \times 10^{-6}$ \\
\hline & 80 & 65 & 0.910 & $1.25 \times 10^{-5}$ \\
\hline & 85 & 65 & 0.977 & $1.70 \times 10^{-5}$ \\
\hline \multirow[t]{5}{*}{$\mathrm{C}$} & 65 & 65 & 0.969 & $2.40 \times 10^{-6}$ \\
\hline & 70 & 65 & 0.873 & $4.17 \times 10^{-6}$ \\
\hline & 75 & 65 & 0.961 & $7.69 \times 10^{-6}$ \\
\hline & 80 & 65 & 0.911 & $1.11 \times 10^{-5}$ \\
\hline & 85 & 65 & 0.887 & $1.42 \times 10^{-5}$ \\
\hline \multirow[t]{5}{*}{$\mathrm{D}$} & 65 & 65 & 0.951 & $4.99 \times 10^{-6}$ \\
\hline & 70 & 65 & 0.943 & $8.33 \times 10^{-6}$ \\
\hline & 75 & 65 & 0.966 & $1.30 \times 10^{-5}$ \\
\hline & 80 & 65 & 0.900 & $1.82 \times 10^{-5}$ \\
\hline & 85 & 65 & 0.929 & $2.19 \times 10^{-5}$ \\
\hline \multirow[t]{5}{*}{ E } & 65 & 65 & 0.958 & $4.11 \times 10^{-6}$ \\
\hline & 70 & 65 & 0.949 & $7.01 \times 10^{-6}$ \\
\hline & 75 & 65 & 0.990 & $1.62 \times 10^{-5}$ \\
\hline & 80 & 65 & 0.910 & $1.45 \times 10^{-5}$ \\
\hline & 85 & 65 & 0.949 & $2.05 \times 10^{-5}$ \\
\hline
\end{tabular}

要望がなかったことから $90^{\circ} \mathrm{C}, 25 \% \mathrm{RH}$ の条件は僅か ながら範囲外となっているが，短期間であればこの条 件に制御は可能である。現装置で数週間のような長期 間の連続使用は若干問題があるが，装置に手を加える ことによって対応は十分可能とのことである。

$80^{\circ} \mathrm{C}, 65 \% \mathrm{RH}$ の条件はいずれも制御範囲内にある。

\section{2 精度}

恒温恒湿器の精度については, 日本試験機工業会規 格 JTM K 01-1985 「恒温恒湿槽の性能基準」に温度 (湿度) 変動幅 ${ }^{(1)}$ と温度 (湿度) 分布( $\left.{ }^{2}\right)$ の 2 項目につ いて定義と算出方法が詳細に規定されている。

各メーカーのカタログに記载されている数值は変動

注 (1) 温度 (湿度) 変動幅……槽の中心に打ける平均 最高温度 (温度) 乙平均最低温度 (湿度) の差

注 $\left(^{2}\right)$ 温度 (湿度) 分布……槽の中心の温度 (温度) 之有効内容積の他の任意の点における温度（湿 度)の差 
幅が $\pm 0.2 \sim 0.5^{\circ} \mathrm{C}, \pm 2 \sim 3 \% \mathrm{RH}$ 程度, 分布幅が \pm $0.5 \sim 0.2^{\circ} \mathrm{C}, \pm 3 \sim 6 \% \mathrm{RH}$ 程度である。

実際に試料が受ける温湿度のバラッキは時間的変動 と槽内の位置的分布が複雑に絡み合ったもので，試料 に対する実効値を把握することは殆ど不可能であろう。 敩密な処理を必要と寸る場合には, 装直の精度につ いても十分考虑に入れておく必要がある。

\section{6. あとがき}

紙の劣化問題は記録という紙の 3 大機能の 1 つを啮 るがしている大さな問題であり，また 100 年を単位と するような超長期を対象とした課題である。今後も少 化に係る研究は息長く地道に続けられるであろらが， J. TAPPI 試験方法 No. 50 “紙及び板紙の加速少化処 理条件”及び本報がいささかでも投役に立てば幸いで ある。

終りに当試験方法の制定及び本報のまとめに当り, 種々御指導下さった東京農工大学農学部大江教授, 東 京大学農学部田田教授, 並びに恒温恒湿器についての
資料及び情報を御提供頂いたタハイエスペック侏に厚 く感謝申し上げる。

\section{引用文献}

1) P. Luner, ' 86 Suga International Weathering Symposium Proceedings (1986)

2) E. L. Graminski, E. J. Parks, and E. E. Toth, The Effects of Temperature and Moisture on the Accelerated Aging of Paper, NBSIR 781443 (1978)

3) E. L. Graminski, E. J. Parks, and E. E. Toth, The Effects of Temperature and Moisture on the Accelerated Aging of Paper, ACS Symposium Series No. 95, Durability of Macromolecular Materials

4）尾関昌幸，大江礼三郎，三浦定俊，紙，ㅇ技協誌， 39, (2) 233 (1985)

5）大江礼三郎, 古田 拓, “紙の少化速度に関する 試験”，段ボール古紙織維少化回復に関する調查 解告㫪, 69-96 (1986)

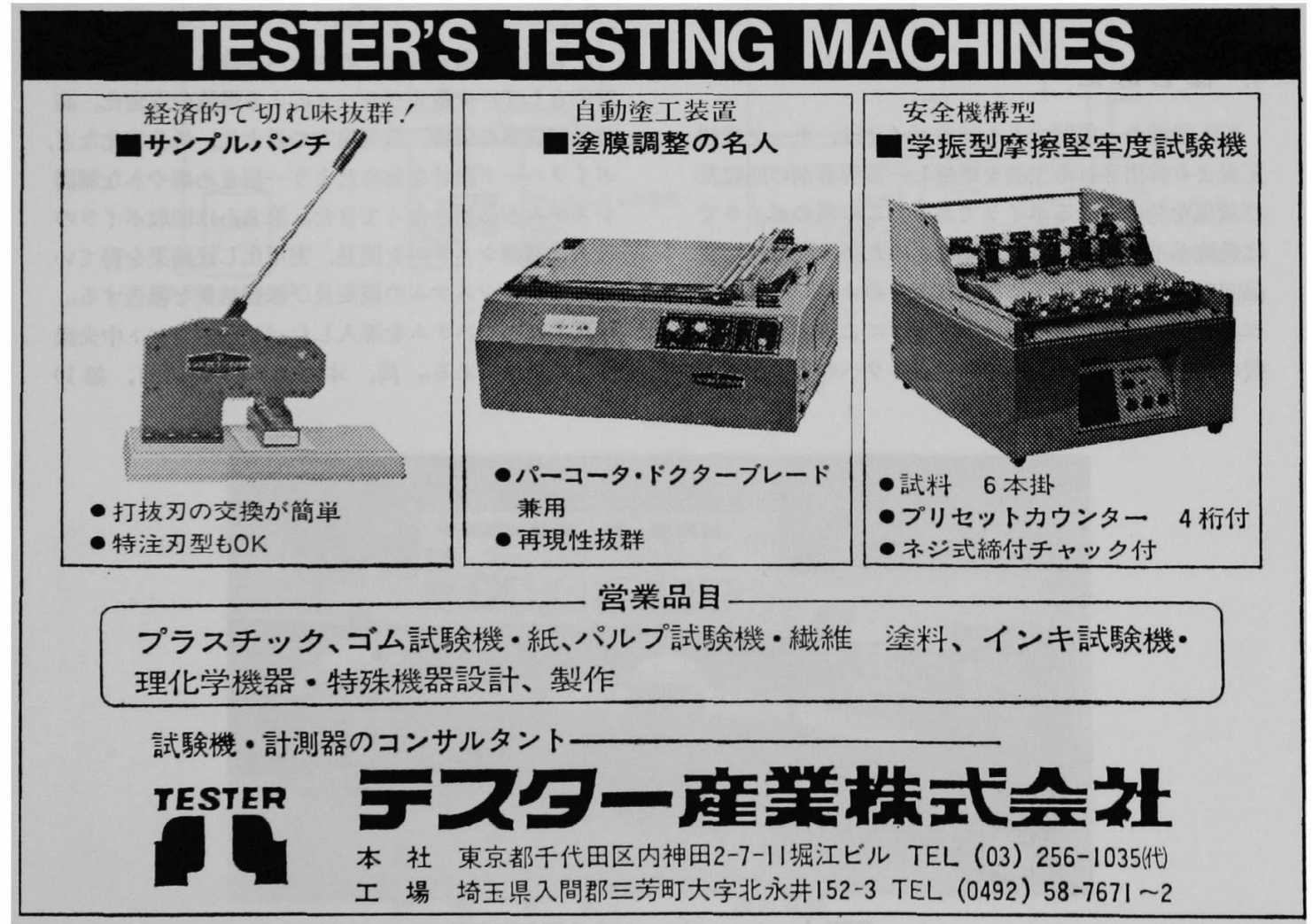

